\title{
Corporate Governance in
}

\section{Nederland: Aandeelhouderswaarde} versus stakeholderwaarde

Henk W. Volberda

\begin{abstract}
Inleiding ${ }^{1}$
De vraag of beursgenoteerde ondernemingen enkel de belangen van haar aandeelhouders zouden moeten behartigen of ook die van alle andere betrokken stakeholders, staat al geruime tijd ter discussie. In het Nederlandse poldermodel werd deze vraag van oudsher beantwoord door de nadruk te leggen op de belangen van de verschillende stakeholders en relaties in netwerken rondom bedrijven. Gedurende de laatste decennia zijn er in Nederland echter steeds meer invloeden waarneembaar vanuit het Angelsaksische model, waarin niet de belangen van stakeholders maar die van de aandeelhouders centraal staan (Heemskerk, 2007; Moerland, 1995). Dit blijkt onder meer uit de recente maatschappelijke discussies betreffende topsalarissen en de rol van de overheid en de banken tijdens de recente financiële crisis. Ondanks deze brede maatschappelijke aandacht voor deze thematiek is er verder echter relatief weinig bekend over deze ontwikkelingen in Nederland. In welke mate heeft het Angelsaksische model bijvoorbeeld voet aan de grond gekregen in Nederland? En is het terecht dat aan deze veranderingen zo vaak een negatieve invloed op de prestaties van Nederlandse ondernemingen wordt toegeschreven? En wie heeft er eigenlijk substantieel bijgedragen aan de verspreiding van deze alternatieve logica in de Nederlandse context?
\end{abstract}

\section{Aandeelhouderswaardeoriëntatie in Nederland}

Om zicht te krijgen op de mate waarin het Angelsaksische model zich gedurende de laatste decennia daadwerkelijk in Nederland heeft verspreid, is de inhoud van meer dan 1700 jaarverslagen geanalyseerd van top-100 beursgenoteerde bedrijven in Nederland gedurende de periode 19922009 (Bezemer, 2010; Bezemer e.a., 2012). De resultaten van onze inhoudsanalyse laten een duidelijke toename van de Angelsaksische benadering zien in Nederland: daar waar $13 \%$ van de top-10o beursgenoteerde bedrijven in 1992 aandeelhouderswaarde (of een equivalent daarvan) noemt in het jaarverslag, is dit percentage in 2009 gestegen naar $79 \%$ (zie grafiek 1). Opvallenderwijs is er vanaf de laatste twee jaar van onze analyse een duidelijke afname waar te nemen in het aantal top-10o ondernemingen dat een aandeelhouderswaardeoriëntatie onderschrijft (van $86 \%$ van de top-100 bedrijven in 2007 naar respectievelijk $79 \%$ in 2009). Deze bevinding lijkt te suggereren dat de economische crisis mogelijk een kentering teweeg heeft gebracht in de wijze waarop bedrijven aandeelhouderswaarde benaderen, hoewel de toekomst zal moeten uitwijzen hoe definitief deze teruggang daadwerkelijk is.

De top-10o beursgenoteerde bedrijven die verwijzen naar aandeelhouderswaarde in hun jaarverslag, implementeren ook vaker mechanismen die geassocieerd worden met een aandeel-houderswaardeoriëntatie: (i) managementsystemen met een nadruk op economische waarde-concepten (bijvoorbeeld EVA), (ii) aandelen- of optieregelingen, (iii) inkoopprogramma's voor eigen aandelen en (iv) presentatie van de jaarcijfers volgens internationale accountancystandaarden. Daarmee lijkt daadwerkelijk sprake te zijn van een verandering in de bedrijfsfilosofie van de top-100 beursgenoteerde ondernemingen in Nederland.

\section{Oorzaken van de groeiende focus op aandeelhouderswaarde in Nederland}

Welke factoren hebben nu bijgedragen aan de wereldwijde verspreiding van een aandeelhouderswaardeoriëntatie? Uit onderzoek blijkt dat twee groepen invloedrijke aandeelhouders een grote rol hebben gespeeld in deze ontwikkeling (Bezemer e.a., 2012). Allereerst blijkt dat top-100 beursgenoteerde bedrijven eerder geneigd zijn om aandeelhouderswaarde in hun jaarverslag te benadrukken als zij grote aandeelhouders met een financiële achtergrond hebben, zoals banken, participatiemaatschappijen, hedgefondsen en en pensioenfondsen. Deze investeerders staan namelijk zelf onder druk van de globale financiële markten. Bovendien zijn deze eigenaren zich ook meer bewust van het belang van aandeelhouderswaarde en rendement en vertalen ze dit door naar de bedrijven waarin ze een aanzienlijk belang hebben. Het is hierbij opmerkelijk dat 
dit niet alleen opgaat voor hedgefondsen en participatiemaatschappijen - die veel media-aandacht hebben gekregen - maar voor financiële instellingen over de gehele breedte van het spectrum. Ten tweede blijkt uit de statistische analyses van jaarverslagen dat top-10o Nederlandse ondernemingen vaker aandeelhouderswaarde in hun jaarverslag benadrukken als zij grote aandeelhouders met een Angelsaksische nationaliteit hebben. Daarmee is de toenemende focus op aandeelhouderswaarde in Nederland niet alleen maar een financieel fenomeen, maar spelen de verwachtingspatronen van Angelsaksische investeerders ook een belangrijke rol.

\section{Invloed oriëntatie op aandeelhouderswaarde op prestaties Nederlandse bedrijven}

Welke gevolgen heeft dit uiteindelijk gehad voor de financiële prestaties van bedrijven? Uit het onderzoek komt naar voren dat de toegenomen focus op aandeelhouderswaarde er tot nu toe niet toe geleid heeft dat de prestaties van bedrijven zijn toegenomen: de top-100 beursgenoteerde bedrijven die in hun jaarverslag aandeelhouderswaarde benadrukten, behaalden gemiddeld een rendement op hun totale activa (ROA) dat $24 \%$ lager lag dan dat van ondernemingen die geen nadruk legden op aandeelhouderswaarde in hun jaarverslag (zie grafiek 2). Bovendien lag ook het aandelenrendement (TSR) van bedrijven die aandeelhouderswaarde benadrukten in hun jaarverslag gemiddeld $25 \%$ lager dan bij andere bedrijven (zie grafiek 2). Deze bevindingen laten zien dat de maatschappelijke kritiek in Nederland op het Angelsaksische model niet ongegrond is.

Deze negatieve samenhang tussen aandeelhouderswaardeoriëntatie en de financiële prestaties van ondernemingen kan op verschillende manieren verklaard worden. Allereerst is het denkbaar dat de Angelsaksische denkwijze voor wrijving zorgt in duurzame netwerkrelaties van bedrijven met partijen als leveranciers, klanten en werknemers (Heemskerk, 2007). Het Rijnlandse model functioneert immers op basis van samenwerking, coöperatie en gezamenlijke waardecreatie, terwijl het Angelsaksische model hoofdzakelijk uitgaat van marktwerking, concurrentie en eigenbelang, waardoor de oude relaties verstoord kunnen worden. Daarnaast richt het Angelsaksische governance-model zich meer op kortetermijnresultaten en gaat het voorbij aan gerichte langetermijninvesteringen in kennis, innovatie en personeel, zoals gebruikelijk in het Nederlandse poldermodel (Kalff, 2004). Een andere verklaring is dat de kortetermijnfocus van het Angelsaksische model minder ruimte biedt om risico's te nemen met het oog op de langere termijn (Peters en Weggeman, 2009).

\section{Toekomstige Corporate Governance opvattingen in Nederland}

Het negatieve effect van een aandeelhouderswaardeoriëntatie op de prestaties van beursgenoteerde bedrijven roept

\section{Grafiek 1 De verspreiding van aandeelhouderswaardeoriëntatie in Nederland}

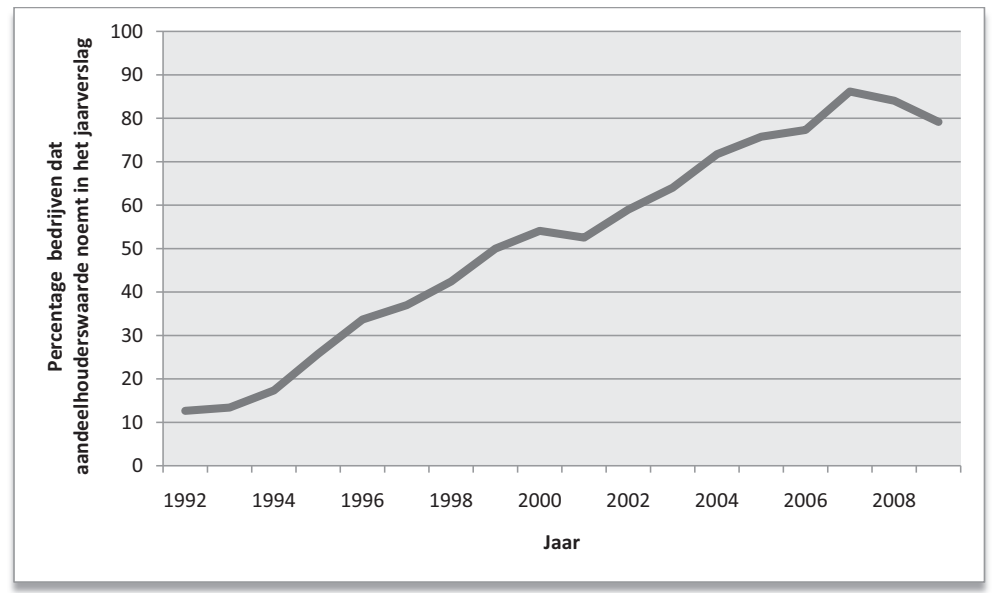

Bron: Bezemer, 2010

\section{Grafiek 2 Gevolgen van een aandeelhouderswaardeoriëntatie ${ }^{1}$}
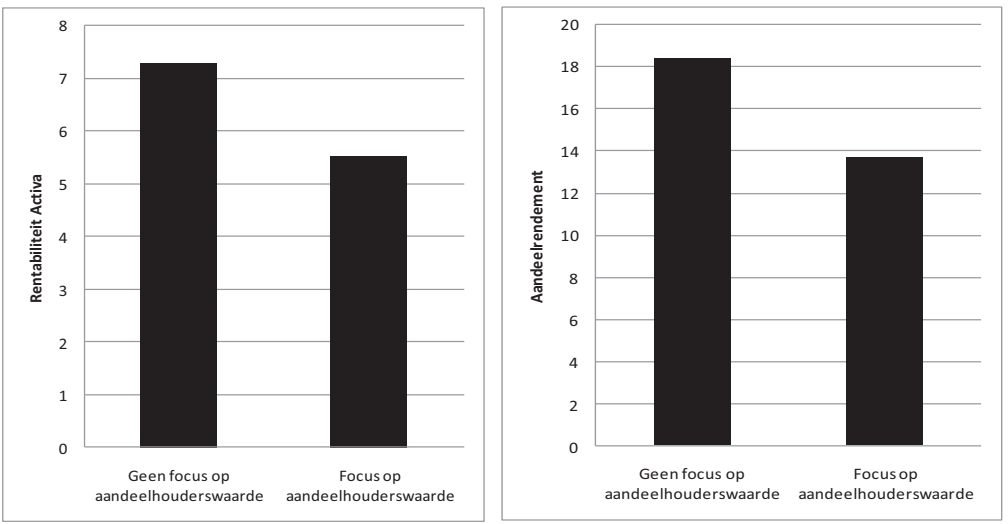

Bron: Bezemer e.a., 2012

de vraag op of het overnemen en implementeren van Angelsaksische principes niet enigszins is doorgeschoten. Als Nederlandse bedrijven daarmee hun eigen prestaties ondermijnen, zouden ze zich moeten bezinnen op de vraag of ze hun Rijnlandse gedachtegoed misschien niet te snel hebben opgegeven in een globaliserende wereld. De onderzoeksbevindingen plaatsen ook vraagtekens bij de toenemende macht en invloed van de aandeelhouder. Gedurende het afgelopen decennium zijn de rechten van de aandeelhouder verruimd, is het aantal beschermingsconstructies afgenomen en is er meer aandeelhoudersactivisme waargenomen in de Nederlandse context. Met het oog op de belangrijke rol van Angelsaksisch-georiënteerde investeerders en financiële instellingen bij de verspreiding van een aandeelhouderswaardeoriëntatie in Nederland, rijst derhalve de vraag of een herbezinning op de huidige checks en balances in het Nederlandse corporate governance-systeem niet op zijn plaats is. 
Daarnaast laten de resultaten zien dat het aannemen van corporate governance-opvattingen die haaks staan op de gangbare logica in een nationale context, niet altijd productief is. Dat maant tot enige voorzichtigheid bij het implementeren van dit soort nieuwe ideeën. Tot slot is een belangrijke maatschappelijke vraag die zich nu aandient in hoeverre de huidige financiële crisis een blijvende kentering teweeg zal brengen in deze ontwikkeling, zoals grafiek 2 lijkt te suggereren. Hoewel de populariteit van

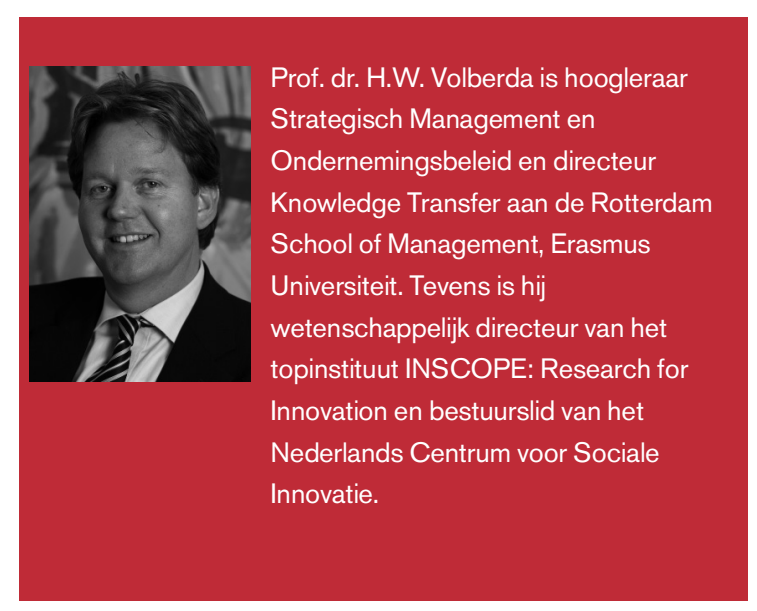

een aandeelhouderswaardeoriëntatie aan het begin van het decennium - rond de val van de beurskoersen en de verschillende corporate governance-schandalen zoals Enron en Ahold - een tijdelijke terugval laat zien, bleek de toename ervan in Nederland toendertijd vrij robuust. Of dit nu opnieuw het geval zal zijn, zal de toekomst moeten uitwijzen. De onderzoeksresultaten suggereren in ieder geval dat verdere voorzichtigheid op zijn plaats is.

\section{Noten}

Deze column is gebaseerd op het binnenkort te verschijnen hoofdstuk 'Aandeelhouderswaarde versus stakeholderwaarde: Een analyse van de ontwikkelingen in Nederland (1992-2009)' van
P.J. Bezemer, F.A.J. Van den Bosch en H.W. Volberda in het Jaarboek Corporate Governance. 2. Data gebaseerd op de gemiddelde rentatbiliteit en het gemiddelde aandelenrendement gedu- rende de periode 1992-2009; t-tests laten zien dat de verschillen significant zijn.

\section{Literatuur}

- Bezemer, P. (2010), Diffusion of corporate governance beliefs: Board independence and the emergence of a shareholder value orientation in the Netherlands, Rotterdam, ERIM doctoral dissertation.

- Bezemer, P., F.A.J. van den Bosch en H.W. Volberda (2012), Aandeelhouderswaarde versus stakeholderwaarde: Een analyse van de ontwikkelingen in Nederland (1992-2009),

Jaarboek Corporate Governance.

- Heemskerk, E.M. (2007), Decline of the corporate the corporate community: Network dynamics of the Dutch Business Elite, Amsterdam: Amsterdam University Press.

- Kalff, D. (2004), Onafhankelijkheid voor Europa: Het eind van het Amerikaanse ondernemingsmodel, Amsterdam: Business Contact.

- Moerland, P.W. (1995), Alternative disciplinary mechanisms in different corporate systems, Journal of Economic Behavior \& Organization, vol. 26, pp. 17-34.

- Peters, J. en M. Weggeman (2009), Het Rijnland boekje, Amsterdam: Business Contact. 